\title{
A pilot study of therapeutic plasma exchange for serious SARS CoV-2 disease (COVID-19): A structured summary of a randomized controlled trial study protocol
}

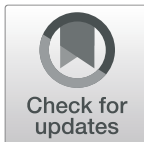

Fahad Faqihi ${ }^{1,2}$, Abdulrahman Alharthy ${ }^{1}$, Mohammed Alodat ${ }^{1}$, Daood Asad ${ }^{1}$, Waleed Aletreby ${ }^{1}$, Demetrios J. Kutsogiannis ${ }^{3}$, Peter G. Brindley ${ }^{3}$ and Dimitrios Karakitsos ${ }^{1,45^{*}}$ (iD

\begin{abstract}
Objectives: To evaluate the safety of therapeutic plasma exchange (TPE) in adult patients with serious/lifethreatening COVID-19 requiring intensive care unit (ICU) admission, and associated 28-day mortality. Serious and life threatening COVID-19 are defined as per published literature (please, refer to the full protocol, Additional file 1). The rationale is that TPE can remove interleukins-3, 6, 8, 10, interferon-gamma and tumor necrosis factor-alpha. Thus, it may reduce the cytokine release syndrome associated with fulminant COVID-19 disease.

Trial design: Pilot, interventional, open-label, randomized controlled multicenter trial.

Participants: Inclusion criteria are: 1) age $\geq 18$ years old; 2) intubation and intensive care unit (ICU) admission; 3) serious and/or life-threatening COVID-19 (please, refer to the full protocol, Additional file 1). SARS-CoV-2 infection is confirmed by Real-Time-Polymerase-Chain-Reaction (RT-PCR) assays using QuantiNova Probe RT-PCR kit (Qiagen) in a Light-Cycler 480 real-time PCR system (Roche, Basel, Switzerland).

Exclusion criteria are: 1) previous allergic reaction to plasma exchange or its ingredients (i.e., sodium citrate), 2) two consecutive negative RT-PCR tests for SARS-CoV-2 at least 24 hours apart, 3) mild COVID-19 not requiring ICU admission and 4) terminally ill patients receiving palliative care. The primary site will be King Saud Medical City (KSMC), Riyadh, Kingdom of Saudi Arabia (KSA). Also, the study will run in ICUs (Ministry of Health Cluster 1; Riyadh) and other centers in KSA pending their institutional review board (IRB) approval.

(Continued on next page)
\end{abstract}

\footnotetext{
*Correspondence: karakitsosdimitrios@gmail.com; d.karakitsos@ksmc.med.sa

${ }^{1}$ Critical Care Department, King Saud Medical City, Riyadh, Kingdom of Saudi Arabia

${ }^{4}$ Department of Internal Medicine, School of Medicine, South Carolina University, Columbia, SC, USA

Full list of author information is available at the end of the article
}

(c) The Author(s). 2020 Open Access This article is licensed under a Creative Commons Attribution 4.0 International License, which permits use, sharing, adaptation, distribution and reproduction in any medium or format, as long as you give appropriate credit to the original author(s) and the source, provide a link to the Creative Commons licence, and indicate if changes were made. The images or other third party material in this article are included in the article's Creative Commons licence, unless indicated otherwise in a credit line to the material. If material is not included in the article's Creative Commons licence and your intended use is not permitted by statutory regulation or exceeds the permitted use, you will need to obtain permission directly from the copyright holder. To view a copy of this licence, visit http://creativecommons.org/licenses/by/4.0/. The Creative Commons Public Domain Dedication waiver (http://creativecommons.org/publicdomain/zero/1.0/) applies to the data made available in this article, unless otherwise stated in a credit line to the data. 
(Continued from previous page)

Interventions and comparator: The intervention group will receive TPE, plus empiric treatment for COVID-19. TPE is administered using the Spectra Optia TM Apheresis System equipped with commercially available cartridges). The first dose is 1.5 plasma volumes, followed by one plasma volume on alternate days or daily for five to seven total treatments. Spectra Optia TM Apheresis System operates with acid-citrate dextrose anticoagulant (ACDA) as per Kidney Disease Improving Global Outcomes (KDIGO) 2019 guidelines. Plasma is replaced with albumin 5\% or fresh frozen plasma in patients with coagulopathy (prothrombin time $>37$ seconds; international normalized ratio $>3$; activated partial thromboplastin time $>100$ or fibrinogen level $<100$ mg/d). TPE sessions are performed daily over four hours and laboratory markers measured daily. The comparators are controls not receiving TPE but usual empiric treatment for COVID-19 as per institutional, national and international recommendations. Both groups will receive standard ICU supportive care.

Main outcomes: Primary study end-point is 28-day mortality and safety of TPE in serious and/or life-threatening COVID-19. Safety will be evaluated by the documentation of any pertinent adverse and/or serious adverse effects related to TPE as per institutional, national and international (Food and Drug Administration) guidelines. Secondary outcomes are: i) improvement in Sequential Organ Function Assessment (SOFA) score ; ii) changes in inflammatory markers: serum C-reactive protein, lactate dehydrogenase, ferritin, d-dimers and interleukin-6; iii) days on mechanical ventilation and ICU length of stay.

Randomization: Eligible consented patients are randomized (1:1 allocation) after stratification by ICU center and two PaO2/FIO2 ratio categories (> 150 and $\leq 150$ ). Randomization occurs in variable block sizes of four to eight patients. A web-based randomization service, randomize.net, is used to allocate patients to their respective strata prior to the intervention or control therapy.

Blinding (masking): Given the visibility of TPE machinery, the intervention will be unblinded; hence, no enrollment concealment will be expedited. The lack of allocation concealment will be mitigated by several measures (please, refer to the full protocol, Additional file 1).

Numbers to be randomized (sample size): This pilot randomized trial aims to recruit a convenience sample of patients with serious and/or life-threatening COVID-19. Therefore, at least 20 patients are to be randomized to each group per participating center. We are hoping to consent and randomize approximately 60 patients in each group over a 3 to 6 months period giving a total of 120 participants.

Trial Status: The protocol version 1 was approved 29/04/2020. Recruitment is ongoing, and began on 01/05/2020. We estimate completion by 29/10/2020.

Trial registration: Registered at ISRCTN on 18/05/2020 (ISRCTN21363594; doi.10.1186/ ISRCTN21363594).

Full protocol: The full protocol is attached as an additional file, accessible from the Trials website (Additional file 1). In the interest of expediting dissemination of this material, the familiar formatting has been eliminated; this letter serves as a summary of the key elements of the full protocol.

Keywords: COVID-19, Randomized controlled trial, Protocol, Therapeutic plasma exchange, Intensive care unit, Lifethreatening COVID-19, Cytokine release syndrome, Acute respiratory distress syndrome, Multisystem organ failure

\section{Supplementary information}

Supplementary information accompanies this paper at https://doi.org/10. 1186/s13063-020-04454-4.

Additional file 1. Full study protocol.

\footnotetext{
Acknowledgements

We thank Ms. Zahra Alfrdan for her secretarial support and all the members of the COVID-19 Crisis Management Team at King Saud Medical City and at Al Imam Abdulrahman Al Feisal Hospital: Ms. Huda Ahmad Mhawish (Head of ICU nursing staff), Mr. Basel Hamid Almuabbadi, Ms. Bobby Rose Marasigan, Ms. Karen Joyce Calamba, Ms. Mary Bay Obra, Ms. Ashley Diane Cabrales, Ms. Faranadz Fazar, Mr. Anil Kumar, Ms. Katrina Baguisa, Ms. Anitha Vargese and Mr. Ayman Alsalmi (Head of Respiratory Therapists). Finally, we acknowledge all health-care workers involved in the diagnosis and treatment of COVID-19 patients in Riyadh, KSA.
}

\section{Authors' contributions}

FF, AA, MA and DA, will provide the therapeutic plasma exchange to eligible subjects. WA is responsible for the statistical design and data collection and analysis. PJB, DJK and DK designed the entire study and wrote the study protocol. All authors read and approved the final manuscript.

\section{Funding}

King Saud Medical City will provide funding that will facilitate collection, analysis, and interpretation of data of this study.

\section{Availability of data and materials}

DK will have access to the final trial dataset. The dataset will be available from the corresponding author upon reasonable request. The contact e-mail address is karakitsosdimitrios@gmail.com

\section{Ethics approval and consent to participate}

Approved by the Institutional Review Board of King Saud Medical City, Riyadh, Kingdom of Saudi Arabia, protocol/serial number: H-01-R-053, 
IORG0010374, H1R1-29-Apr20-01. This trial has received ethical approval from the appropriate ethical committee as described above. Written informed

consent will be obtained by all eligible patients or their legal representatives.

\section{Consent for publication}

Not Applicable

\section{Competing interests}

The authors declare that they have no competing interests.

\section{Author details}

${ }^{1}$ Critical Care Department, King Saud Medical City, Riyadh, Kingdom of Saudi Arabia. ${ }^{2}$ Critical Care Department, Al Imam Abdulrahman Al Feisal Hospital, Riyadh, Kingdom of Saudi Arabia. ${ }^{3}$ Department of Critical Care, Faculty of Medicine and Dentistry, The University of Alberta, Edmonton, AB, Canada.

${ }^{4}$ Department of Internal Medicine, School of Medicine, South Carolina University, Columbia, SC, USA. ${ }^{5}$ Critical Care Department, Keck Medical School, USC, Los Angeles, CA, USA.

Received: 24 May 2020 Accepted: 24 May 2020

Published online: 08 June 2020

\section{Publisher's Note}

Springer Nature remains neutral with regard to jurisdictional claims in published maps and institutional affiliations.

Ready to submit your research? Choose BMC and benefit from:

- fast, convenient online submission

- thorough peer review by experienced researchers in your field

- rapid publication on acceptance

- support for research data, including large and complex data types

- gold Open Access which fosters wider collaboration and increased citations

- maximum visibility for your research: over $100 \mathrm{M}$ website views per year

At BMC, research is always in progress.

Learn more biomedcentral.com/submissions 